University of Nebraska - Lincoln

DigitalCommons@University of Nebraska - Lincoln

Faculty Papers and Publications in Animal

Science

Animal Science Department

$1-1-1991$

\title{
INFLUENCE OF GROWTH RATE AND EXPOSURE TO BULLS ON AGE AT PUBERTY IN BEEF HEIFERS
}

\author{
M. S. Roberson \\ University of lowa, msr14@cornell.edu
}

M. W. Wolfe

Case Western Reserve University, mwolfe2@kumc.edu

T. T. Stumpf

L. A. Werth

University of Nebraska-Lincoln

Andrea S. Cupp

University of Nebraska-Lincoln, acupp2@unl.edu

See next page for additional authors

Follow this and additional works at: https://digitalcommons.unl.edu/animalscifacpub

Part of the Animal Sciences Commons

Roberson, M. S.; Wolfe, M. W.; Stumpf, T. T.; Werth, L. A.; Cupp, Andrea S.; Kojima, N.; Wolfe, P. L.; Kittok, Roger J.; and Kinder, J. E., "INFLUENCE OF GROWTH RATE AND EXPOSURE TO BULLS ON AGE AT PUBERTY IN BEEF HEIFERS" (1991). Faculty Papers and Publications in Animal Science. 164.

https://digitalcommons.unl.edu/animalscifacpub/164

This Article is brought to you for free and open access by the Animal Science Department at DigitalCommons@University of Nebraska - Lincoln. It has been accepted for inclusion in Faculty Papers and Publications in Animal Science by an authorized administrator of DigitalCommons@University of Nebraska - Lincoln. 


\section{Authors}

M. S. Roberson, M. W. Wolfe, T. T. Stumpf, L. A. Werth, Andrea S. Cupp, N. Kojima, P. L. Wolfe, Roger J. Kittok, and J. E. Kinder 


\title{
INFLUENCE OF GROWTH RATE AND EXPOSURE TO BULLS ON AGE AT PUBERTY IN BEEF HEIFERS 1,2
}

\author{
M. S. Roberson ${ }^{3}$, M. W. Wolfe ${ }^{4}$, T. T. Stumpf, \\ L. A. Werth, A. S. Cupp, N. Kojima, \\ P. L. Wolfe, R. J. Kittok and J. E. Kinder ${ }^{5}$ \\ University of Nebraska-Lincoln, \\ Lincoln 68583-0908
}

\begin{abstract}
Two experiments were conducted to test the following hypotheses: 1) exposure of beef heifers to sterile bulls increases the proportion of heifers attaining puberty by 14 mo of age and 2) rate of growth interacts with bull exposure to influence age at puberty in beef heifers. In Exp. I, heifers were assigned to one of two treatments: 1) heifers were exposed to bulls (BE; approximately 70-d period of exposure) or 2) heifers were isolated from bulls (NE) and served as controls. In Exp. II, heifers were assigned to either BE or NE treatments (175-d period of exposure to bulls) and were fed to gain at a moderate (MG; .6 $\mathrm{kg} / \mathrm{d}$ ) or high (HG; .8 kg/d) growth rate. Blood samples were collected twice weekly to determine concentrations of progesterone indicative of onset of corpus luteum function and puberty. In Exp. I a greater $(P<.05)$ proportion of heifers receiving the BE treatment than of heifers receiving the NE treatment initiated corpus luteum function by 14 mo of age. In Exp. II, there was a bull exposure $\times$ growth rate interaction $(P<.05)$. The effect of bull exposure was greater within the HG groups than within the MG groups. However, heifers fed to attain a moderate or high growth rate and exposed to bulls attained puberty at younger ages than heifers not exposed to bulls and fed to attain a moderate or high growth rate. Mean ages at puberty were $375,422,428$, and 449 (pooled $S E M=8.6$ ) d for heifers in the BE-HG, BE-MG, NE-HG, and NE-MG groups, respectively. Therefore, we accept our working hypothesis that exposure of heifers to bulls increased the proportion of heifers attaining puberty by the initiation of breeding at $14 \mathrm{mo}$ of age. Furthermore, growth rate interacts with the stimulatory influence(s) of bulls to influence age at puberty in beef heifers.
\end{abstract}

Key Words: Bulls, Exposure, Growth Rate, Puberty, Pregnancy Rate, Heifers

J. Anim. Sci. 1991. 69:2092-2098

\section{Introduction}

${ }^{1}$ Published as paper No. 9261 Journal Ser. Nebraska Agric. Res. Div.

${ }^{2}$ We thank Laura Rife for her patience in preparation of this manuscript; Karl Moline, Jeff Bergman and Bob Browleit for management of the experimental animals; and Ken Pearson and Georgette Caddy for technical assistance with hormone analysis.

${ }^{3}$ Current address: Dept. of Physiol. and Biophysics, Univ. of Iowa, Iowa City 52242.

${ }^{4}$ Current address: Dept. of Pharmacol., Case Western Reserve Univ., Cleveland, OH 44106.

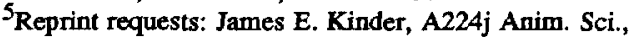
Univ. of Nebraska, Lincoln, NE 68583-0908.

Received July 2, 1990.

Accepted November 27, 1990.
Izard and Vandenbergh (1982) reported that oronasal administration of bull urine to prepuberal heifers resulted in an increased proportion of heifers attaining puberty during an 8-wk treatment period. They speculated that bull urine contained a priming pheromone that hastened the onset of puberty in heifers. A similar hypothesis is supported by data demonstrating that urine from male mice accelerated the onset of puberty in female mice (Colby and Vandenbergh, 1974). The observations on cattle are inconsistent with these findings. Data 
reported by Berardinelli et al. (1978) and MacMillian et al. (1979) indicate that shortterm exposure of heifers to bulls had no influence on age at puberty in heifers. Roberson et al. (1987) also reported that long-term exposure of heifers to mature bulls did not influence age at puberty in beef heifers.

Age at attainment of puberty in beef heifers is influenced by plane of nutrition and growth rate (Short and Bellows, 1971; Mosely et al., 1982; Day et al., 1986). In the study reported by Izard and Vandenbergh (1982), responsiveness of prepuberal heifers to potential pheromonal cues from bulls seemed to be dependent on BW of heifers. In addition, Stumpf et al. (1987) reported that bull exposure and level of feed intake interacted to reduce the interval to first estrus after parturition in mature cows. Therefore, two experiments were conducted to test the following hypotheses: 1) exposure of prepuberal heifers to bulls results in an increased proportion of heifers attaining puberty by $14 \mathrm{mo}$ of age (Exp. I) and 2) rate of growth of heifers interacts with exposure to bulls to influence age at puberty in beef heifers (Exp. II).

\section{Materials and Methods}

\section{Experiment $I$}

Experimental Protocol. Prepuberal beef heifers ( $n=267$; approximately $350 \mathrm{~d}$ of age; $1 / 3$ Hereford $\times 1 / 3$ Red Angus $\times 1 / 3$ Shorthorn) were used over a 4-yr period (1984 to 1987). Before initiation of treatments within each year, all heifers were weaned from cows in November and were managed as a single group. Within each year heifers were assigned to one of two treatments: 1 ) exposure to bulls (BE) or 2) isolation from bulls (NE). Heifers averaged $11.6 \mathrm{mo}$ of age at the time the treatments were applied and averaged $14.1 \mathrm{mo}$ of age at the time of cessation of the treatment period. The treatment period ended at the time of initiation of the natural breeding season (Table 1). Two mature epididectomized bulls were placed with heifers that received the $\mathrm{BE}$ treatment each year. Heifers that received the NE treatment were managed in pastures that were approximately $2 \mathrm{~km}$ from heifers that received the $\mathrm{BE}$ treatment. Therefore, isolation from the stimulatory influence of bulls was assumed. Water, brome grass hay, and mineral supplement were available ad libitum.
Radioimmunoassays. Beginning at the initiation of treatments, blood samples were collected via jugular venipuncture from all heifers twice weekly. Blood samples were allowed to clot on ice and stored for $24 \mathrm{~h}$ at $4^{\circ} \mathrm{C}$. Serum from these samples was stored at $-20^{\circ} \mathrm{C}$ until it was assayed for progesterone. Concentrations of progesterone in serum samples were determined by RIA (Anthony et al., 1981). Intra- and interassay CV were 4.6 and $12.8 \%$, respectively.

Criteria for Attainment of Puberty. Initiation of corpus luteum function was determined to have occurred when concentrations of progesterone were $\geq 1 \mathrm{ng} / \mathrm{ml}$ of serum for two consecutive samples followed by cyclic ovarian function or pregnancy. These characteristics of ovarian function were used as an indicator of attainment of puberty in heifers. Concentrations of progesterone $<1 \mathrm{ng} / \mathrm{ml}$ of serum in blood samples collected during the first 2 wk of the study within each year from heifers receiving both treatments were indicative of prepuberty. Heifers determined to be puberal during the first 2 wk of the study were excluded from the trial.

Statistical Analysis. Initial attempts to use survival analysis methods (Lifereg procedures; SAS, 1985) to estimate age at puberty in heifers that did not exhibit cyclic ovarian function by the end of the study failed because of small numbers of heifers reaching puberty in the NE treatment group. Thus, differences in proportions of heifers attaining puberty by 14 mo of age were analyzed by chi-square analysis (Steel and Torrie, 1980).

\section{Experiment II}

Experimental Protocol. Prepuberal beef heifers (1/4 Pinzgauer, 1/4 Red Poll, 1/4 Angus, $1 / 4$ Hereford; $n=159$ ) were used in Exp. II over a 2-yr period (1988 to 1989). Before the initiation of this study, heifers were weaned from cows and managed similarly to heifers in Exp. I. Within each year, heifers were randomly assigned to one of four treatments: 1) BE and high growth rate (BEHG; $n=20 / y r)$; 2) $B E$ and moderate growth rate (BE-MG; $n=19$ or $20 / y r) ; 3$ ) NE and HG (NE-HG; $n=20 / y r)$; or 4 ) NE and MG (NEMG; $n=20 / y r)$. The target growth rates for heifers receiving the HG and MG treatments were .8 and $.6 \mathrm{~kg} / \mathrm{d}$, respectively.

All heifers received ad libitum access to brome grass hay, mineral supplement, and 
TABLE 1. SUMMARY OF NUMBER OF HEIFERS USED, INITIAL AGE, LENGTH OF PERIOD OF BULL EXPOSURE, AND CUMULATTVE PERCENTAGES OF HEIFERS ATTAINING PUBERTY AT THE TIME OF INITLATION OF BREEDING AT 14 MONTHS OF AGE IN EXP. I

\begin{tabular}{|c|c|c|c|c|c|c|}
\hline \multirow{2}{*}{$\begin{array}{l}\text { Year and } \\
\text { treatment }\end{array}$} & \multirow[b]{2}{*}{$\mathbf{n}$} & \multirow{2}{*}{$\begin{array}{l}\text { Initial } \\
\text { age, d }\end{array}$} & \multirow{2}{*}{$\begin{array}{l}\text { Length of } \\
\text { exposure } \\
\text { period, } d^{b}\end{array}$} & \multicolumn{3}{|c|}{$\begin{array}{c}\text { Percentage puberal by } \\
\text { age, mo }\end{array}$} \\
\hline & & & & 12 & 13 & 14 \\
\hline \multicolumn{7}{|l|}{1984} \\
\hline $\begin{array}{l}\mathbf{B E} \\
\mathbf{N E}\end{array}$ & $\begin{array}{l}34 \\
33\end{array}$ & $\begin{array}{l}370 \\
369\end{array}$ & 66 & $\begin{array}{r}14.7 \\
6.1\end{array}$ & $\begin{array}{l}41.2 \\
33.3\end{array}$ & $\begin{array}{l}61.8 \\
45.4\end{array}$ \\
\hline \multicolumn{7}{|l|}{1985} \\
\hline $\begin{array}{l}\mathbf{B E} \\
\mathbf{N E}\end{array}$ & $\begin{array}{l}32 \\
32\end{array}$ & $\begin{array}{l}352 \\
361\end{array}$ & 70 & $\begin{array}{r}15.6 \\
3.1\end{array}$ & $\begin{array}{l}53.1^{*} \\
12.5\end{array}$ & $\begin{array}{l}56.3 * \\
21.9\end{array}$ \\
\hline \multicolumn{7}{|l|}{1986} \\
\hline $\begin{array}{l}\text { BE } \\
\text { NE }\end{array}$ & $\begin{array}{l}33 \\
34\end{array}$ & $\begin{array}{l}338 \\
341\end{array}$ & 78 & $\begin{array}{l}21.6 \\
11.8\end{array}$ & $\begin{array}{l}42.4^{*} \\
11.8\end{array}$ & $\begin{array}{l}51.5^{*} \\
17.6\end{array}$ \\
\hline \multicolumn{7}{|l|}{1987} \\
\hline $\begin{array}{l}\mathbf{B E} \\
\mathbf{N E}\end{array}$ & $\begin{array}{l}37 \\
32\end{array}$ & $\begin{array}{l}327 \\
323\end{array}$ & 88 & $\begin{array}{l}45.9^{*} \\
21.9\end{array}$ & $\begin{array}{l}67.6^{*} \\
34.4\end{array}$ & $\begin{array}{l}70.3^{*} \\
34.4\end{array}$ \\
\hline \multicolumn{7}{|l|}{ Overall } \\
\hline $\begin{array}{l}\text { BE } \\
\text { NE }\end{array}$ & $\begin{array}{l}136 \\
131\end{array}$ & $\begin{array}{l}347 \\
349\end{array}$ & 76 & $\begin{array}{l}25.0 \\
10.0\end{array}$ & $\begin{array}{l}51.5^{*} \\
22.9\end{array}$ & $\begin{array}{l}60.3^{*} \\
29.8\end{array}$ \\
\hline Pooled SEM & & 4.3 & 4.9 & & & \\
\hline
\end{tabular}

${ }^{\text {aTreatments: }} \mathrm{BE}=$ exposed to bulls; $\mathrm{NE}=$ not exposed to bulls.

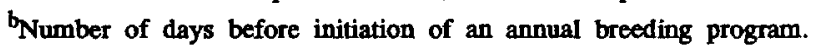

*BE vs NE $(P<.05)$.

water. An energy supplement containing 50\% corn and $50 \%$ alfalfa pellets was provided each day and intake was adjusted on a monthly basis during the 175-d treatment period to obtain the target growth rates. The goal of the two growth rates was to attain a moderate rate of gain generally typical of heifers raised at the University of Nebraska and a high rate of gain that would result in an $18-$ to $25-\mathrm{kg}$ advantage in BW following the initial $90 \mathrm{~d}$ of the study. At the initiation of the study each year, heifers were $268 \pm 6 \mathrm{~d}$ of age and $248 \pm 7 \mathrm{~kg} \mathrm{BW}$. Mature epididectomized bulls (2 to $3 \mathrm{yr}$ of age) were used with both groups of heifers receiving the $B E$ treatment at a ratio of one bull to 19 or 20 heifers. Epididectomized bulls were rotated between treatment groups at monthly intervals throughout the study. Body weights were recorded for individual heifers at 2-wk intervals.

Heifers were maintained in treatment groups from December 16 to June 7. In both years beginning on May 17, a 21-d period of artificial insemination (AI) was implemented. Heifers in each treatment group were observed for behavioral estrus for $1 \mathrm{~h}$ twice daily (a.m. and p.m.) during the AI period. Heifers were inseminated by an AI technician (the same technician made all of the inseminations) $12 \mathrm{~h}$ after detection of behavioral estrus. After the period of $\mathrm{Al}$, heifers in all treatment groups were placed in a single pasture and supplementation was stopped. Fertile bulls were placed with heifers for a 30-d period of natural service breeding (June 8 to July 8). Pregnancy was determined in heifers by palpation per rectum $90 \mathrm{~d}$ after the end of the period of natural service breeding. Day of parturition was recorded for all heifers to confirm AI pregnancies based on a gestation length of $280 \mathrm{~d}$.

Radioimmunoassays. Beginning at the initiation of treatments, blood samples were collected and processed as described in Exp. I. Collection of blood samples continued through the end of the period of natural service breeding. Concentrations of progesterone in serum were determined by RIA (Roberson et al., 1989). Intra- and interassay CV were 3.6 and $11.2 \%$, respectively. The same criteria as described in Exp. I were used to determine the onset of cyclic corpus luteum function indicative of puberty. Concentrations of progesterone in heifers were also used to verify that accuracy of estrous detection was not biased by the presence of bulls. Pregnancy resulting from AI was also verified by a sustained rise 
TABLE 2. INITIAL AGE, GROWTH RATES, AND AGE AND WEIGHT AT PUBERTY IN HEIFERS FROM EXP. II

\begin{tabular}{|c|c|c|c|c|c|c|}
\hline \multirow[b]{2}{*}{ Treatment $^{\mathrm{a}}$} & \multicolumn{2}{|c|}{$\begin{array}{l}\text { Initial } \\
\text { age, d }\end{array}$} & \multirow{2}{*}{$\begin{array}{l}\text { Growth } \\
\text { rate, } \\
\mathrm{kg} / \mathrm{d}\end{array}$} & \multicolumn{2}{|c|}{$\begin{array}{c}\text { Age at } \\
\text { puberty, } \mathrm{d}^{\mathrm{b}}\end{array}$} & \multirow{2}{*}{$\begin{array}{l}\text { Pu- } \\
\text { berty } \\
\text { wt, } \\
\mathrm{kg}^{\mathrm{c}}\end{array}$} \\
\hline & Yr 1 & Yr 2 & & Yr 1 & Y. 2 & \\
\hline BE-HG & 273 & 263 & .82 & 358 & 391 & 322 \\
\hline BE-MG & 275 & 266 & .63 & 417 & 427 & 340 \\
\hline NE-HG & 272 & 264 & .77 & 427 & 428 & 363 \\
\hline NE-MG & 274 & 264 & .65 & 456 & 441 & 369 \\
\hline Pooled SEM & 6.4 & 4.9 & .02 & 8.5 & 8.7 & 5.7 \\
\hline
\end{tabular}

Trearments: $\mathrm{BE}=$ exposed to bulls; $\mathrm{NE}=$ not exposed to bulls; $\mathrm{HG}=$ high growth rate; $\mathrm{MG}=$ moderate growth rate; $\mathbf{n}=19$ or $20 \cdot$ group $^{-1} \cdot \mathrm{yr}^{-1}$.

bull exposure $x$ year interaction $(P<.05)$. Therefore, data from each year were analyzed separately; bull exposure $\times$ growth rate interaction $(P<.05)$.

${ }^{c}$ There were no treatment $\times$ year interactions for weight at puberty; thus, data from both years were combined; bull exposure $\times$ growth rate $(P>.05)$; effect of bull exposure $(P<.05)$, effect of growth rate $(P<.05)$.

in concentrations of progesterone in heifers that were bred by AI.

Statistical Analysis. Data regarding BW change reflecting growth rate of heifers were analyzed by growth curve analysis (Allen et al., 1983). Analysis of variance and orthogonal contrasts (Steel and Torrie, 1980) were used to test for differences in age and weight at puberty and mean day of parturition due to main effects and their interaction. Proportions of heifers becoming pregnant to $\mathrm{AI}$ and during the period of natural service breeding were analyzed by chi-square analysis (Steel and Torrie, 1980).

\section{Results}

\section{Experiment I}

During the initial year of Exp. I (1984), there was no difference $(P>.05)$ between treatment groups in the proportions of heifers attaining puberty by 12,13 , or 14 mo of age (Table 1). During yr 2, 3, and 4 (1985 to 1987) a greater $(P<.05)$ proportion of heifers that received the $\mathrm{BE}$ treatment than of heifers receiving the NE treatment attained puberty by 12,13 , or 14 mo of age (Table 1 ).

\section{Experiment II}

There was no treatment $x$ year interaction $(P>.05)$ for growth rates of heifers, so data from both years were combined. Body weight increased $(P<.05)$ in a linear fashion $\left(\mathrm{R}^{2}=\right.$ $.55)$ in heifers in all treatment groups. Growth rates were greater $(P<.05)$ in heifers receiving the HG treatment than in heifers receiving the MG treatment across BE or NE treatments (Table 2).

Greater than $97 \%$ of heifers over both years of the study initiated corpus luteum function during the experimental period. There was a bull exposure $\times$ year interaction $(P<.05)$ for age at puberty in heifers across both growth rates. Thus, data regarding age at puberty for heifers from each year were analyzed separately. In addition, there was a bull exposure $x$ growth rate interaction $(P<.05)$ for age at puberty for heifers within each year. During yr 1 and 2 , the effect of bull exposure was greater within the HG treatment groups than within the MG treatment groups. However, when considering both feed intake levels, heifers that were exposed to bulls attained puberty at younger ages (Table 2). The bull exposure $x$ year interaction results from the magnitude of differences in age at puberty in heifers receiving the BE-HG and NE-MG treatments during yr 2 , which was approximately $45 \%$ less than during yr 1 .

There were no treatment $\times$ year or bull exposure $\times$ growth rate interactions $(P>.05)$ for weight at puberty; therefore, data from both years were combined. The rankings for weight at puberty from lightest to heaviest were $\mathrm{BE}$ $\mathrm{HG}<\mathrm{BE}-\mathrm{MG}<\mathrm{NE}-\mathrm{HG}=\mathrm{NE}-\mathrm{MG}$ (Table 2). Heifers receiving the $\mathrm{HG}$ treatments were 12.1 $\pm 4 \mathrm{~kg}$ lighter $(P<.05)$ at puberty than heifers receiving the $M G$ treatments across $B E$ treatments. Furthermore, heifers receiving the $\mathrm{BE}$ treatments were $35.2 \pm 4 \mathrm{~kg}$ lighter $(P<.05)$ at 
TABLE 3. PROPORTIONS OF HEIFERS BECOMING PREGNANT TO AI AND AI PLUS NATURAL SERVICE BREEDING (OVERALL PREGNANCY) FROM EXP. II

\begin{tabular}{|c|c|c|c|}
\hline Treatment $^{\mathbf{a}}$ & $\begin{array}{l}\text { AI } \\
\text { pregnancy, } \%\end{array}$ & $\begin{array}{l}\text { Overall } \\
\text { pregnancy, \% }\end{array}$ & $\begin{array}{l}\text { Mean day of } \\
\text { parturition } \\
\text { (Julian d) }\end{array}$ \\
\hline BE-HG & $50^{c}$ & $85^{c}$ & 67.7 \\
\hline BE-MG & $51^{\mathrm{c}}$ & $87^{c}$ & 72.4 \\
\hline NE-HG & $25^{d}$ & $88^{c}$ & 76.9 \\
\hline NE-MG & $8^{d}$ & $72^{c}$ & 81.5 \\
\hline Pooled SEM & & & 2.4 \\
\hline
\end{tabular}

aTreatments: $\mathrm{BE}=$ exposed to bulls; $\mathrm{NE}=$ not exposed to bulls; $H G=$ high growth rate; $M G=$ moderate growth rate; $\mathbf{n}=19$ or $20 \cdot$ group $^{-1} \cdot \mathrm{yr}^{-1}$.

b There were no treatment $x$ year or bull exposure $x$ growth rate interactions for mean day of parturition; thus, data from both years were combined; effect of bull exposure $(P<.06)$; effect of growth rate $(P<.06)$.

$c, \mathrm{~d}_{\text {Numbers }}$ or proportions with different superscripts within a column differ $(P<.05)$.

puberty than heifers receiving the NE treatments across growth rates.

There were no treatment $\times$ year or bull exposure $\times$ growth rate interactions $(P>.05)$ for pregnancy rate and day of parturition; therefore, data from both years were combined. Pregnancy rates to AI were greater $(P<.05$; Table 3) in heifers receiving the BE-HG and BE-MG treatments than in heifers receiving the NE-HG and NE-MG treatments. No effects of growth rate or its interaction with BE were observed $(P>.05)$. Overall pregnancy rates in heifers did not differ (Table 3). The main effects of bull exposure and growth rate decreased date at parturition $(P<.06$; Table $3)$.

\section{Discussion}

The results of the present study are consistent with observations reported by Izard and Vandenbergh (1982) and support the hypothesis that social interactions between bulls and prepuberal heifers result in a decreased age at attainment of puberty. However, this hypothesis is not supported by observations reported by Berardinelli et al. (1978) and MacMillian et al. (1979), who evaluated the effects of shortterm bull exposure, or by the data of Roberson et al. (1987), who exposed heifers to bulls for periods of time similar to those used in Exp. II.

Our original premise in conducting Exp. II was that inherent differences in growth rates of heifers may have contributed to the inconsistent results reported in the aforementioned literature. Results from Exp. II do support the conclusion that bull exposure interacts with growth rates of heifers to alter age at attainment of puberty. However, an effect of bull exposure was observed within both levels of feed intake studied in the present experiment. Therefore, variation in rate of growth of heifers likely does not adequately explain inconsistencies in observations reported by Roberson et al. (1987) and those of the present experiment. A number of other factors may explain these inconsistencies, including differences in rate of gain during the experimental period (i.e., a curvilinear vs linear rate of gain over time), differential ability of bulls to elicit a response, or inherent differences due to biological type, location, season, or other undefined factors.

The nature of the interaction between bull exposure and growth rate observed in the present study is inconsistent with results reported by Stumpf et al. (1987) in cows following parturition. In that study, cows fed to attain a moderate body condition and exposed to bulls initiated estrous cycles following parturition at a point in time equivalent to that at which cows with high body condition that were exposed to bulls initiated estrus. These data suggest that cows fed to attain a lower body condition were more responsive to the stimulatory influences of bull exposure than were cows with inherently higher levels of body condition. In the present study, a response to bull exposure was observed in heifers gaining $\mathrm{BW}$ at a moderate and high rate; however, the magnitude of the response to bull exposure decreased as rate of gain decreased. Relatively small changes in growth rate seem to influence the potential responsiveness of heifers (changes in age at puberty) to the stimulatory effects of bull exposure.

The increase in proportions of heifers receiving the BE-HG and BE-MG treatments that became pregnant to AI compared with heifers receiving the other treatments reflects the increased proportions of heifers that attained puberty by the end of the period of AI in Exp. II. Overall pregnancy rates were similar among heifers in all treatment groups in Exp. II. A relatively large proportion of heifers receiving the NE treatments initiated estrous cycles after the initiation of the period of natural service breeding (50 and $80 \%$ in 
NE-HG and NE-MG, respectively). Heifers in all treatment groups were placed in a single group during the period of natural service breeding, so many factors, such as exposure to intact bulls and puberal heifers, may have influenced the relatively rapid attainment of puberty in heifers that were prepuberal at the end of the period of AI. In addition, heifers were greater than $400 \mathrm{~d}$ of age at the start of natural service breeding. Therefore, the possibility exists that attainment of puberty in heifers would have occurred regardless of social interaction between sexes.

In wild and feral populations of several mammalian species (Hasler and Banks, 1975; Baddaloo and Clulow, 1981; Massey and Vandenbergh, 1981) and laboratory mice (Vandenbergh, 1967; Colby and Vandenbergh, 1974; Vandenbergh et al., 1974), the presence of the male or his urine accelerates the onset of puberty in females. This effect in the mouse has been attributed to an androgen-dependent urinary pheromone produced by the male (Vandenbergh et al., 1974). In domestic ruminants, social interaction between sexes is usually limited to a discrete breeding season defined by management systems. The duration of postpartum anestrus in multiparous and primiparous cows was decreased when cows were exposed to bulls following parturition (Zalesky et al., 1984; Alberio et al., 1987; Custer et al., 1988; Gifford et al., 1989). Results from the present study indicate that the attainment of puberty in heifers is accelerated when heifers are exposed to bulls. The role of pheromonal or other allelomimetic cues in acceleration of the onset of cyclic ovarian function at puberty remains to be determined in the bovine. This male effect seems to be dependent in part on environmental interactions such as growth rate of heifers. Based on data from the present studies we accept our working hypotheses that exposure of prepuberal heifers to bulls increases the proportions of heifers attaining puberty between 12 and 14 mo of age. Furthermore, growth rate of heifers interacts with the stimulatory influence(s) of bull exposure to accelerate the attainment of puberty.

\section{Implications}

The role of bull exposure in accelerating the onset of ovarian function during sexual maturation and after parturition may be beneficial to reproductive management and lifetime productivity in the bovine female. The possibility exists that management of heifers during sexual development may be optimized by a profitable tradeoff between feed resources and bull exposure. However, cautious evaluation of such management decisions is required because the magnitude of response to bull exposure decreases as rate of gain of heifers decreases.

\section{LIterature Clted}

Alberio, R. H., G. Schiersmann, N. Carou and J. Mestre. 1987. Effect of a teaser bull on ovarian and behavioural activity of suckling beef cows. Anim. Reprod. Sci. 14: 263.

Allen, O. B., J. H. Burton and J. D. Holt. 1983. Analysis of repeated measurements from animal experiments using polynomial regression. J. Anim. Sci. 57:765.

Anthony, R. V., R. J. Kittok, E. F. Ellington and M. K. Nielsen. 1981. Effect of zeranol on growth and ease of calf delivery in beef heifers. J. Anim. Sci. 53:1325.

Baddaloo, E.G.Y. and F. V. Clulow. 1981. Effects of the male on growth, sexual maturation, and ovulation of young female meadow voles, Microtus Pennsylvanicus. Can. J. Zool. 59:415.

Berardinelli, J. G., R. L. Fogwell and E. K. Inskeep. 1978. Effect of electrical stimulation or presence of a bull on puberty in beef heifers. Theriogenology 9:133.

Colby, D. R. and J. G. Vandenbergh. 1974. Regulatory effects of urinary pheromones on puberty in the mouse. Biol. Reprod. 11:268.

Custer, E. E., J. G. Berardinelli, M. E. Wehrman, R. Adair and R. E. Short. 1988. Postpartum interval to estrus and patterns of luteinizing hormone (LH) concentrations in first-calf suckled beef heifers exposed to mature bulls. J. Anim. Sci. 66(Suppl. 1):412 (Abstr.).

Day, M. L., K. Imakawa, D. D. Zalesky, R. J. Kittok and J. E. Kinder. 1986. Effects of restriction of dietary energy intake during the prepubertal period on secretion of luteinizing hormone and responsiveness of the pituitary to luteinizing hormone-releasing hormone in heifers. J. Anim. Sci. 62:1641.

Gifford, D. R., M. J. D'Occhio, P. H. Sharpe, T. Weatherly, R. Y. Pittar and D. V. Reeve. 1989. Return to cyclic ovarian activity following parturition in mature cows and first-calf heifers exposed to bulls. Anim. Reprod. Sci. 19:209.

Hasler, J. F. and E. M. Banks. 1975. The influence of mature males on sexual maturation in female collard lemmings (Dicrostonyx Groenlandicus). J. Reprod. Fertil. 42:583.

Izard, M. K. and J. G. Vandenbergh. 1982. The effects of bull urine on puberty and calving date in crossbred beef heifers. J. Anim. Sci. 55:1160.

MacMillian, K. L., A. J. Allison and G. A. Struthers. 1979. Some effects of running bulls with suckling cows or heifers during the premating period. N. Z. J. Exp. Agric. 7:121.

Massey, A. and J. G. Vandenbergh. 1981. Puberty acceleration by a urinary cue from male mice in feral populations. Biol. Reprod. 24:523. 
Mosely, W. M., T. G. Dunn, C. C. Kaltenbach, R. E. Short and R. B. Staigmiller. 1982. Relationship of growth and puberty in beef heifers fed monensin. J. Anim. Sci. 55:357.

Roberson, M. S., R. P. Ansotegui, J. G. Berardinelli, R. W. Whitman and M. J. McInerney. 1987. Influence of biostimulation by mature bulls on occurrence of puberty in beef heifers. J. Anim. Sci. 64:1601.

Roberson, M. S., M. W. Wolfe, T. T. Stumpf, R. J. Kittok and J. E. Kinder. 1989. Luteinizing hormone secretion and corpus lutenm function in cows receiving two levels of progesterone. Biol. Reprod. 41:997.

SAS. 1985. SAS User's Guide: Statistics. SAS Inst., Inc., Cary, NC.

Short, R. E. and R. A. Bellows. 1971. Relationships among weight gains, age at puberty and reproductive performance in heifers. J. Anim. Sci. 32:127.

Steel, R.D.G. and J. H. Torrie. 1980. Principles and
Procedures of Statistics: A Biometrical Approach (2nd Ed.). McGraw-Hill Book Co., New York.

Stumpf, T. T., M. W. Wolfe, P. L. Wolfe, M. L. Day, R. J. Kittok and J. E. Kinder. 1987. Interaction of bull exposure and level of nutritional intake on the duration of postpartum anestrus. J. Anim. Sci. 65(Suppl. 1):417 (Abstr.).

Vandenbergh, J. G. 1967. Effect of the presence of a male on the sexual maturation of female mice. Endocrinology $81: 345$.

Vandenbergh, J. G., J. M. Whitsett and J. R. Lombardi. 1974. Partial isolation of a pheromone accelerating puberty in female mice. J. Reprod. Fertil. 43:515.

Zalesky, D. D., M. L. Day, M. Garcia-Winder, K. Imakawa, R. J. Kittok, M. J. D'Occhio and J. E. Kinder. 1984. Influence of exposure to bulls on resumption of estrous cycles following parturition in beef cows. J. Anim. Sci. 59:1135. 